\title{
Effect of Head and Tongue Posture on the Pharyngeal Airway Dimensions and Morphology in Three-Dimensional Imaging: a Systematic Review
}

\author{
Sirwan Fernandez Gurani', Gabriele Di Carlo ${ }^{2,3}$, Paolo M. Cattaneo ${ }^{2}$, Jens Jørgen Thorn ${ }^{1}$, \\ Else Marie Pinholt ${ }^{1,4}$ \\ ${ }^{1}$ Department of Oral \& Maxillofacial Surgery, Hospital of South West Denmark, Esbjerg, Denmark. \\ ${ }^{2}$ Section of Orthodontics, Department of Dentistry, Faculty of Health Science, Aarhus University, Aarhus, Denmark. \\ ${ }^{3}$ Department of Oral and Maxillofacial Science, Sapienza University of Rome, Rome, Italy. \\ ${ }^{4}$ Faculty of Health Sciences, Institute of Regional Health Services Sciences, University of Southern Denmark, Denmark.
}

\author{
Corresponding Author: \\ Else Marie Pinholt \\ Finsensgade 35, 6700, Esbjerg \\ Denmark \\ Phone: +4540161358 \\ E-mail: empinholt@health.sdu.dk
}

\begin{abstract}
Objectives: Natural head position is recommended to be optimal at cone-beam computed tomography acquisition. For standardization purposes in control of treatment outcome, it is clinically relevant to discuss, if a change of posture from natural head position may have an effect on the pharyngeal airway dimensions and morphology, during computed tomography, conebeam computed tomography or magnetic resonance imaging acquisition. This was the aim of the present literature review study for purposes of valid evidence, which was hypothesized, to be present.

Material and Methods: This systematic literature review has been registered in PROSPERO database with following number: CRD42015024567. A systematic literature search performed in PubMed, Embase and Cochrane was carried out in order to evaluate if the effect of human head or tongue posture has an effect on upper airway dimensions and morphology in CT, CBCT or MRI. Study quality assessment was performed. Predictor variable was head and tongue posture. Endpoints were numerical values of upper airway dimensions and morphology.

Results: Overall 1344 articles (Embase 1063, PubMed 269, and Cochrane 12) resulted in four included publications. Quality assessments revealed poor quality and low-level evidence by 46 - 67\% of the maximum achievable score. Heterogeneous methodology made a meta-analysis impossible, consequently a narrative synthesis was performed.

Conclusions: Limited, poor quality and low evidence level literature is available on the effect of head posture on upper airway dimensions and morphology in three-dimensional imaging. Valid evidence requires a standardized method of head and tongue posture during image acquisition in future studies.
\end{abstract}

Keywords: cone-beam computed tomography; magnetic resonance imaging; obstructive sleep apnea; orthognathic surgery; posture.

Accepted for publication: 25 February 2016

To cite this article:

Gurani SF, Di Carlo G, Cattaneo PM, Thorn JJ, Pinholt EM.

Effect of Head and Tongue Posture on the Pharyngeal Airway Dimensions and Morphology in Three-Dimensional Imaging: a Systematic Review

J Oral Maxillofac Res 2016;7(1):e1

URL: http://www.ejomr.org/JOMR/archives/2016/1/e1/v7n1e1.pdf

doi: $10.5037 /$ jomr.2016.7101 


\section{INTRODUCTION}

Upper airway evaluation includes nasopharyngoscopy, cephalometrics, computed tomography (CT), magnetic resonance imaging (MRI) and cone-beam computed tomography (CBCT) in visualization and measurement of the pharyngeal airway volume [1-7]. Three-dimensional imaging evaluation supplies important information on the possible effect of orthognathic surgery in obstructive sleep apnea (OSA) $[\underline{4}, \underline{6}, \underline{8-10}]$.

In particular, $\mathrm{CBCT}$ has become today's method of choice and is considered a reliable X-ray tool in diagnostics, treatment planning and outcome control in respect to different treatment modalities $[\underline{4}, \underline{6}, \underline{7}$, 11-14].

CBCT is characterized by a lower effective radiation dosage, lower cost, easy accessibility and somehow shorter acquisition time compared to $\mathrm{CT}$ and MRI $[\underline{6}, \underline{8}, \underline{9}, \underline{12}]$.

Studies of the upper airway based on CBCT scans are considered to be reliable in defining the border between soft tissues and void spaces (i.e. air) thus providing important information about the morphology (i.e. cross-sectional area and volume) of the pharyngeal airway $[\underline{4}, \underline{11}]$. However, CBCT has its limitation, compared to MRI and $\mathrm{CT}$, in distinguishing between different types of soft tissues bordering the upper airway (i.e. muscles, connective tissue, fat, etc.) [4].

Instructions from the manufacturers of the CBCT X-ray equipment, define the natural head position (NHP) to be the optimal posture at CBCT acquisition. For purposes of standardization and for outcome control after surgical procedures comprising orthognathic surgery due to maxillofacial abnormalities or in conjunction with OSA, it is of utmost importance to be able to perform repeatable acquisitions of CBCT X-rays. Numerous publications $[\underline{4}, \underline{8-10}, 12]$ discussed the importance of control of head posture at CBCT imaging of the upper airway and they also suggested studies for comparison of qualitative- and quantitative evaluations of the effect of head posture on upper airway measures.

The effect of orthognathic surgery on changes of upper airway dimensions and volume was evaluated by three-dimensional imaging techniques in several studies [15-18]. Surgical maxillomandibular advancement is an effective treatment modality of OSA, possibly due to enlargement of the upper airways [19-21]. Results on the effect of maxillary advancement and mandibular setback on the pharyngeal airway volume are somehow conflicting
[22-24]. The total upper airway volume changes were reported to be statistically significant smaller in the studies by Hong et al. [24] and Lee et al. [22] while Jakobsone et al. [23] found an increase in the upper airway volume 6 months after surgery.

Upper airway dimension and morphology is dependent on the patient's head posture and the cranio-cervical inclination during two-dimensional radiographic image acquisition [25-27]. Back in 1958, Moorrees and Kean [28] strained the importance of head posture in the interpretation of cephalograms, and Solow and co-authors [29-31] have claimed the influence of airway obstruction on head posture.

On lateral cephalograms Hellsing [26] reported that a change from NHP to 20 degrees extension resulted in an increase of the pharyngeal cross-sectional airway dimension, and Muto et al. [27] found similar results when he reported that an increase of 10 degrees in the cranio-cervical inclination subsequently increased the pharyngeal airway space by about $4 \mathrm{~mm}$.

However, lateral cephalograms suffer from different limitations: distortion, magnification, and superimposition of bilateral craniofacial structures which is in contrast to three-dimensional assessment, which is able to overcome the classical drawbacks characterizing the lateral radiography [4].

Although changes of head posture and tongue posture have been reported after orthognathic surgery, the possible influence of tongue or head posture on the upper airway dimensions and morphology has not yet been focused on [32-35].

In order to perform repeatable acquisitions of CBCT $\mathrm{X}$-rays comprising comparable measures, qualitative and quantitative studies ought to systematically include evaluation of how head posture was controlled since it may affect such results.

For this reason the aim of this study was to review the literature regarding: 1) if standardization exists using three-dimensional imaging (CT, CBCT or MRI) and 2) if studies exist on the influence of head and tongue posture on the pharyngeal airway dimensions and morphology using threedimensional imaging.

\section{MATERIAL AND METHODS Protocol and registration}

This systematic literature review has been registered in PROSPERO database (www.crd. york.ac.uk/PROSPERO) with following number: CRD42015024567. 


\section{Focus question}

The focus question developed according to the population, intervention, comparison, outcome and study design (PICOS) is presented in Table 1.

\section{Information sources}

The search was performed in PubMed (National Library of Medicine, NCBI) (www.ncbi.nlm.nih. gov/pubmed/), Embase and Cochrane databases on December 1, 2015.

\section{Search strategy}

The search sequence comprised several keywords and MeSH terms for a broad coverage of the subject. The search consisted of a combination of the following three headlines: 1) three-dimensional imaging, 2) upper airway and 3) head and tongue posture as presented in Table 2.
The predictor variable was head posture/tongue posture, and the primary outcome was dimensional and morphological changes of the upper airway measured in numerical values as an effect of altered head - or tongue posture.

\section{Study selection \\ Inclusion and exclusion criteria}

Exclusively English-language was the restriction of the search. The obtained references from the three databases were subjected to a screening process, where titles and abstracts were reviewed to discover papers regarding the effect of head and tongue posture on the upper airway dimensions and morphology, and evaluated by three-dimensional imaging (CT, CBCT or MRI).

An article were included if it contained human studies in that aspect.

Table 1. PICOS table

\begin{tabular}{l|l}
\hline \multicolumn{1}{c|}{ Component } & \multicolumn{1}{c}{ Description } \\
\hline Population & Clinical patient studies that evaluate the effect of specific head posture on the volume of the upper airway. \\
\hline Intervention & Altered head position/inclination. \\
\hline Comparison & Valid numerical measurement of the airway volume. \\
\hline Outcome & Changes in the head position and airway volume. \\
\hline Study design & Randomized and non-randomized controlled trials, and cohort studies. No restriction. \\
\hline
\end{tabular}

Table 2. Search in PubMed database (National Library of Medicine, NCBI) performed on December 1, 2015

\begin{abstract}
Three-dimensional imaging:
(cone-beam computed tomography OR volumetric radiography OR volumetric tomography OR digital volumetric radiography OR digital volumetric tomography OR digital volume tomography OR cbct OR cone-beam ct OR cone beam imaging OR cone-beam OR “cone beam" OR volumetric ct OR conebeam OR cb-ct OR volumetric computed tomography OR X-ray computed tomography OR X-ray computerized tomography OR "CT scans" OR "CT scan" OR "CAT scan" OR "CAT scans" OR (magnetic resonance imaging) OR MRI OR 3D OR 3-D OR 3-dimensional OR three-dimensional
\end{abstract}

\footnotetext{
Upper airway:

(upper airway OR upper airways OR "respiratory tract" OR pharynx OR pharyngeal OR oropharynx OR oropharyngeal OR nasopharynx OR nasopharyngeal OR hypopharynx OR hypopharyngeal))

\section{Head posture/tongue posture:}

(((((Head posture) OR (head postures) OR (head position) OR (head positions) OR (head rotation) OR (head positioning) OR (tongue position) OR (tongue posture) OR (hyoid bone position) OR (position of the hyoid bone) OR (jaw position) OR (jaw positions) OR (mandibular position) OR (mandibular positions))))

Combined keywords and MeSH for the search in PubMed database (National Library of Medicine, NCBI) performed on December 1, 2015:

(cone-beam computed tomography OR volumetric radiography OR volumetric tomography OR digital volumetric radiography OR digital volumetric tomography OR digital volume tomography OR cbct OR cone-beam ct OR cone beam imaging OR cone-beam OR "cone beam" OR volumetric ct OR conebeam OR cb-ct OR volumetric computed tomography OR X-ray computed tomography OR X-ray computerized tomography OR "CT scans" OR "CT scan" OR "CAT scan" OR "CAT scans" OR (magnetic resonance imaging) OR MRI OR 3D OR 3-D OR 3-dimensional OR three-dimensional AND (upper airway OR upper airways OR "respiratory tract" OR pharynx OR pharyngeal OR oropharynx OR oropharyngeal OR nasopharynx OR nasopharyngeal OR hypopharynx OR hypopharyngeal)) AND (((((Head posture) OR (head postures) OR (head position) OR (head positions) OR (head rotation) OR (head positioning) OR (tongue position) OR (tongue posture) OR (hyoid bone position) OR (position of the hyoid bone) OR (jaw position) OR (jaw positions) OR (mandibular position) OR (mandibular positions))))
} 
Inclusion criteria:

- English language;

- Study on humans;

- Three-dimensional studies (CT, MRI or CBCT);

- Evaluation of the effect of head or tongue posture on the upper airway dimensions and morphology.

Exclusion criteria:

- Two-dimensional lateral cephalogram evaluations;

- Case report;

- Literature review.

\section{Data collection process}

The included articles were reviewed in detail by the first two authors (SFG and GDC). Information from each study regarding year of publication, number of patients, gender, mean age, any disorder related to the upper airway, population, intervention, comparison, outcome and study design (PICOS table) as presented in Table 1 were extracted. Additional information about the three-dimensional imaging type, description of the study and main finding of the article, were plotted in Table 3 for further comparison of the studies and assessment of the quality of the obtained articles.

\section{Quality assessment}

In order to assess the quality of the studies, we created a methodological scoring system (Table 4), which constituted different scoring systems validated by Lagravere et al. [36], van Vlijmen et al. [10] and Roscoe et al. [37].

This resulted in Table 4 with 17 criteria applicable and suitable for our topic with focus on study design: time, randomization assignment, control group, sample size, sample gender, objective and selection criteria, study measurements: segmentation method, part of airway, type of airway measurements, airway measurements adjusted, method of acquisition, and blinding measurements method and data analysis: statistical analysis, validation of measurements and data presentation.

Subsequently the studies were scored by the two authors (SFG and GDC) independently and compared and finally discussed in forum with all the authors to reach a consensus (Table 5).

According to van Vlijmen et al. [10], the mean quality (mQ) of the studies can be rated as: $\mathrm{mQ}<60 \%=$ poor quality; $60 \% \leq \mathrm{mQ} \leq 70 \%=$ moderate quality; $\mathrm{mQ}>70 \%=$ good quality.

Consequently, the methodological quality scores were calculated as percentages of the maximum achievable score (24 points) for each study as presented in Table 5.

\section{RESULTS \\ Study selection}

The initial search yielded 1344 references, a result of 1063 articles from Embase, 269 articles from PubMed and 12 articles from Cochrane databases, respectively. In the stage of identification, according to the article selection process 'PRISMA 2009 Flow Diagram' as presented in Figure 1, the duplicate references were removed by a "duplicate finder" tool from EndNote $\mathrm{X} 7$ and manually as well, resulting in 1197 references to 147 duplicate references removal.

In the screening process, titles and when relevant, abstracts from 1197 references were reviewed with the attention to study terms: head posture/tongue posture or head position/tongue position in relation to the pharyngeal airway/upper airway dimensions, evaluated by three-dimensional radiographic imaging/analysis. This screening resulted in the exclusion of 1193 references leaving 4 full-text articles.

\section{Study characteristics}

In Table 3, information from the 4 included articles were extracted and plotted in the PICOS table (Table 1) where data regarding participants, interventions, comparisons, outcomes, study designs (PICOS), type of imaging technique and a short summary of the study and main findings are presented. The four included articles were published between 2000 and 2015, counted between 12 - 60 subjects each, three studies were prospective studies performed exclusively by MRI, one study was retrospective and exclusively performed by $\mathrm{CBCT}$ imaging. The outcome variable in two papers was published in figures, and subsequently the authors were contacted by mail $[38,39]$. Regarding Ono et al. [38], the numerical values were not obtainable since the study was 15 years old and charts not kept. In the study by Pirilä-Parkkinen et al. [푸], data were obtained but however they did not define a specific degree from NHP of head extension or flexion related to airway volume changes. A meta-analysis was therefore not possible to perform due to lack of numerical values of the included 4 articles; hence a narrative study was performed.

\section{Results of quality assessment}

The results of methodological quality score are shown in Table 5, where the scores ranged from 46 to $67 \%$ of the maximum achievable score with a mean quality score of the studies $54 \%$, which is categorized as poor quality by van Vlijmen et al. [10] and thus low level of evidence. The hypothesis was subsequently rejected. 
Table 3. PICOS, three-dimensional imaging type, description of the study and main findings of the included articles

\begin{tabular}{|c|c|c|c|c|c|c|c|c|}
\hline Study & Participants & Interventions & Comparisons & Outcomes & Study design & $\begin{array}{c}\text { Three- } \\
\text { dimensional }\end{array}$ & Short description of the study & $\begin{array}{l}\text { Main findings regarding } \\
\text { airway volume changes }\end{array}$ \\
\hline $\begin{array}{l}\text { Ono et al. } \\
\text { [31] }\end{array}$ & $\begin{array}{l}12 \text { adult males, } \\
\text { mean (SD) age: } 27.8 \\
\text { (3.19) years, no sign } \\
\text { of disorders related } \\
\text { to the upper airway. }\end{array}$ & $\begin{array}{l}\text { Three head/body } \\
\text { positions were } \\
\text { evaluated: supine, } \\
\text { supine with the head } \\
\text { rotated and lateral } \\
\text { recumbent. }\end{array}$ & $\begin{array}{l}\text { Morphologic, } \\
\text { dimensional and } \\
\text { volume changes in } \\
\text { relation to head/ body } \\
\text { positions. }\end{array}$ & \begin{tabular}{|l|} 
Effects of head/ \\
body positions on \\
the morphology, \\
dimension and \\
volume of the upper \\
airway.
\end{tabular} & $\begin{array}{l}\text { Non-randomized } \\
\text { controlled trial. } \\
\text { Prospective } \\
\text { study. }\end{array}$ & MRI & $\begin{array}{l}\text { This study deals with the effects } \\
\text { of head and body position changes } \\
\text { (supine, supine with the head } \\
\text { rotated and lateral recumbent) } \\
\text { on upper airway dimension and } \\
\text { volume in patients examined with } \\
\text { three-dimensional MRI. }\end{array}$ & $\begin{array}{l}\text { The study shows a significant } \\
\text { increase in volume in the } \\
\text { retroglossal region of oropharynx } \\
\text { when the subject rotated his head } \\
\text { to left in the supine position and } \\
\text { when changed from the supine to } \\
\text { the lateral recumbent position. }\end{array}$ \\
\hline $\begin{array}{l}\text { Pirilä- } \\
\text { Parkkinen } \\
\text { et al. [32] }\end{array}$ & \begin{tabular}{|l|}
29 children with \\
SDB (14 boys, 15 \\
girls), mean (SD) \\
age: 7.3 (1.37) \\
years and a control \\
group of 29 age- and \\
gender-matched \\
healthy children. \\
\end{tabular} & $\begin{array}{l}\text { Three different } \\
\text { head postures were } \\
\text { evaluated: neutral, } \\
\text { extension, and } \\
\text { flexion. }\end{array}$ & $\begin{array}{l}\text { Changes of pharyngeal } \\
\text { cross-sectional airway } \\
\text { area }\left(\mathrm{mm}^{2}\right) \text { in relation } \\
\text { to changes of head } \\
\text { postures. }\end{array}$ & $\begin{array}{l}\text { Effects of different } \\
\text { head postures on the } \\
\text { pharyngeal airway } \\
\text { size. }\end{array}$ & $\begin{array}{l}\text { Non-randomized } \\
\text { controlled trail. } \\
\text { Prospective } \\
\text { study. }\end{array}$ & MRI & $\begin{array}{l}\text { This study deals with patients in } \\
\text { different head postures (neutral, } \\
\text { extension and flexion) in MRI } \\
\text { and the effect on the pharyngeal } \\
\text { airway in } 29 \text { children with SDB } \\
\text { and } 29 \text { asymptomatic control } \\
\text { children. }\end{array}$ & $\begin{array}{l}\text { The hypopharyngeal airway in } \\
\text { the SDB group was significantly } \\
\text { increased with head extension } \\
\text { compared to neutral head posture } \\
\text { and the increase was higher } \\
\text { for the SDB group than in the } \\
\text { asymptomatic group. }\end{array}$ \\
\hline $\begin{array}{l}\text { Zhang } \\
\text { et al. [38] }\end{array}$ & $\begin{array}{l}12 \text { subjects ( } 8 \text { male } \\
\text { and } 4 \text { female), mean } \\
\text { (SD) age: } 26.13 \\
\text { (3.21) years, no sign } \\
\text { of disorders related } \\
\text { to the upper airway. }\end{array}$ & $\begin{array}{l}4 \text { different jaw, head } \\
\text { and body positions } \\
\text { were evaluated: jaw } \\
\text { protrusion, supine } \\
\text { with jaw protrusion, } \\
\text { supine-head rotation } \\
\text { with jaw protrusion } \\
\text { and lateral decubitus } \\
\text { with jaw protrusion. }\end{array}$ & $\begin{array}{l}\text { Changes in jaw, head } \\
\text { and body positions in } \\
\text { relation to changes in } \\
\text { A-P dimension, lateral } \\
\text { dimension, cross- } \\
\text { sectional area, and } \\
\text { volume of oropharynx. }\end{array}$ & $\begin{array}{l}\text { Effects of different } \\
\text { jaw, head and body } \\
\text { positions on the A-P } \\
\text { dimension, lateral } \\
\text { dimension, cross- } \\
\text { sectional areal and } \\
\text { volume } \mathrm{cm}^{3} \text { of the } \\
\text { pharyngeal airway at } \\
\text { the retropalatal and } \\
\text { retroglossal region. }\end{array}$ & \begin{tabular}{|l|} 
\\
Non-randomized \\
controlled trail. \\
Prospective \\
study.
\end{tabular} & MRI & $\begin{array}{l}\text { The study looks at the effect of } \\
\text { altering head and body position } \\
\text { on the oropharyngeal airway } \\
\text { dimension and volume examined } \\
\text { by MRI. The four different jaw, } \\
\text { head and body positions: } \\
\text { 1) supine without jaw protrusion, } \\
\text { 2) supine with jaw protrusion, } \\
\text { 3) supine with head rotation and } \\
\text { jaw protrusion and 4) laterally } \\
\text { recumbent position with jaw } \\
\text { protrusion. }\end{array}$ & $\begin{array}{l}\text { The results of the study show } \\
\text { that jaw protrusion increases the } \\
\text { volume }\left(\mathrm{cm}^{3}\right) \text { of oropharynx at } \\
\text { the level of retropalatal region and } \\
\text { retroglossal region compared with } \\
\text { nonprotruded positions. }\end{array}$ \\
\hline $\begin{array}{l}\text { Glupker } \\
\text { et al. [39] }\end{array}$ & $\begin{array}{l}60 \text { female subjects, } \\
\text { mean }(\mathrm{SD}) \text { age: } \\
40,4(17,8) \text { years, } \\
\text { no airway pathology } \\
\text { noted on CBCT. }\end{array}$ & $\begin{array}{l}\text { Closed and open } \\
\text { jaw positions were } \\
\text { evaluated. }\end{array}$ & $\begin{array}{l}\text { Changes in open and } \\
\text { closed jaw position in } \\
\text { relation to } \\
\text { volume of the nasal } \\
\text { cavity, nasopharynx, } \\
\text { and oropharynx; the soft } \\
\text { palate; the soft-tissue } \\
\text { thickness of the airway; } \\
\text { and the most constricted } \\
\text { area of the airway. }\end{array}$ & $\begin{array}{l}\text { Effects of open and } \\
\text { closed jaw positions } \\
\text { on the volume of the } \\
\text { upper airway. }\end{array}$ & $\begin{array}{l}\text { Non-randomized } \\
\text { controlled trail. } \\
\text { Retrospective } \\
\text { study. }\end{array}$ & CBCT & $\begin{array}{l}\text { This study looked at the influence } \\
\text { of open and closed jaw positions } \\
\text { on the upper airway dimensions } \\
\text { in patients who were undergoing } \\
\text { diagnosis and treatment of } \\
\text { temporomandibular disorders. }\end{array}$ & $\begin{array}{l}\text { The results from this study showed } \\
\text { that open jaw position compared } \\
\text { to closed jaw position cause a } \\
\text { significant increase in nasopharynx } \\
\text { whereas the nasal cavity volume, } \\
\text { oropharynx volume, and soft } \\
\text { palate area decrease. }\end{array}$ \\
\hline
\end{tabular}

$\mathrm{SDB}=$ sleep-disordered breathing; $\mathrm{MRI}=$ magnetic resonance imaging; $\mathrm{CBCT}=$ cone-beam computed tomography; $\mathrm{SD}=$ standard deviation. 
Table 4. Methodological scoring system

\section{Criteria assessed}

\section{Study design}

Score

(maximum score $=11$ points)

\section{A. Time \\ B. Randomized sample \\ C. Control group \\ D. Sample size \\ E. Sample gender}

\section{F. Objective}

G. Selection criteria

H. Baseline characteristics

\section{A. Segmentation method}

(manually or automated)

\section{B. Part of airway}

\section{Type of airway measurements}

D. Airway measurements adjusted

E. Method of acquisition F. Blinding measurements method

A. Statistical analysis

B. Validation of measurements (error of the method)

C. Data presentation
Retrospective, 1 point; prospective, 2 point.

If stated, 1 point.

If present, 1 point.

Subjects $\geq 29,1$ point; power of the study estimated before collection of data, 1 point

Both gender included and divided into different groups, 2 points; only male or female, 1 point; both gender included but not divided, 0 point.

Clearly formulated, 1 point

If they are clearly described and relevant to the topic of the paper, 1 point

Similar baseline characteristics, 1 point.

II. Study measurements

(maximum score $=9$ points)

If clearly stated, 1 point.

If the part of airway mentioned consistent with the anatomic definition advocated by Schwab et al. [44] and Guijarro-Martínez et al. [20], 1 point.

Volume, 1 point; partial volume, 1 point, Linear, 1 point; smallest cross section, 1 point.

Adjusted to head position (i.e. craniocervical inclination), 1 point; adjusted to a horizontal plane

(i.e. FHP), 1 point.

If clearly stated, 1 point.

If clearly stated and implemented, 1 point.

\section{Data analysis}

(maximum $=4$ points)

\section{If clearly 5 stated and appropriate for data, 1 point}

If it's stated that the method used had been validated in the present paper or validated in early paper, 1 point.

If P-value stated, 1 point; if any variability measures (standard deviation, confidence interval, or range) stated, 1 point.

Table 5. Methodological scoring system (points) for included articles (total scoring; maximum = 24 points)

\begin{tabular}{l|c|c|c|c}
\hline & Ono et al. [31] & $\begin{array}{c}\text { Pirilä-Parkkinen } \\
\text { et al. [32] }\end{array}$ & Zhang et al. [38] & Glupker et al. [39] \\
\hline \multicolumn{7}{|c}{ I. Study design } \\
(maximum score = 11 points) \\
\hline A. Time & 2 & 2 & 2 & 1 \\
\hline B. Randomized sample & 0 & 0 & 0 & 0 \\
\hline C. Control group & 0 & 1 & 0 & 0 \\
\hline D. Sample size & 0 & 2 & 0 & 1 \\
\hline E. Sample gender & 1 & 0 & 0 & 1 \\
\hline F. Objective & 1 & 1 & 1 & 1 \\
\hline G. Selection criteria & 1 & 1 & 1 & 0 \\
\hline H. Baseline characteristics & 0 & 1 & 0 & 4 \\
\hline \multicolumn{1}{c|}{ Score } & 5 & 8 & 4 & \\
\hline
\end{tabular}

II. Study measurements

(maximum score $=9$ points)

\begin{tabular}{l|l|l|l|l}
\hline $\begin{array}{l}\text { A. Segmentation method } \\
\text { (manually or automated) }\end{array}$ & 0 & 0 & 0 & 0 \\
\hline B. Part of airway & 1 & 1 & 1 & 0 \\
\hline C. Type of airway measurements & 3 & 2 & 3 & 2 \\
\hline D. Airway measurements adjusted & 0 & 0 & 0 & 0 \\
\hline E. Method of acquisition & 1 & 1 & 1 & 0 \\
\hline F. Blinding measurements method & 0 & 0 & 0 & 1 \\
\hline \multicolumn{1}{c|}{ Score } & 5 & 4 & 5 & 3 \\
\hline
\end{tabular}

III. Data analysis

A. Statistical analysis

B. Validation of measurements

(error of the method)

C. Data presentation

Score

Total score

Total score \%

Mean quality \% of the studies

(maximum score $=4$ points)

\begin{tabular}{|c|c|c|c|}
\hline 1 & 1 & 1 & 1 \\
0 & 1 & 0 & 1 \\
\hline 2 & 2 & 2 & 2 \\
\hline 3 & 4 & 3 & 4 \\
\hline 13 & 16 & 12 & 11 \\
\hline $\mathbf{3} 100 \approx 54$ & $16 / 24 \times 100 \approx 67$ & $12 / 24 \times 100 \approx 50$ & $11 / 24 \times 100 \approx 46$ \\
\hline
\end{tabular}




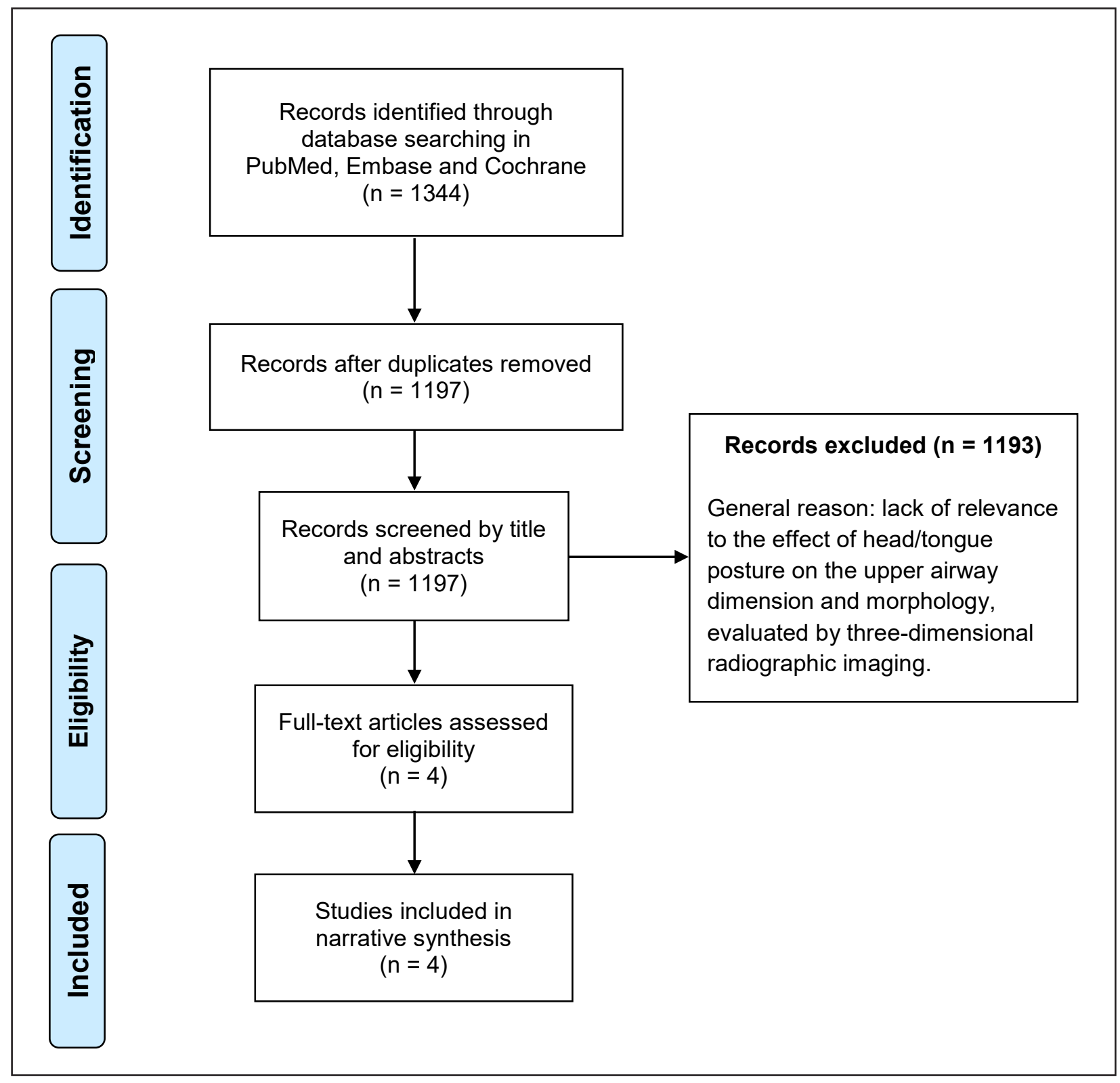

Figure 1. PRISMA flow diagram illustrating the literature search protocol.

\section{DISCUSSION}

Upper airway three-dimensional analysis and evaluation has got a significant attention in the literature due to easier assessment and advantages provided by newer three-dimensional imaging techniques.

The position of head and tongue posture has been mentioned to have a big influence on the upper airway dimension in many studies and it has been warned that bias may evolve as a result of lack of a standardized head and tongue posture at the

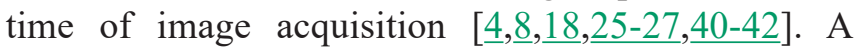
standardized acquisition posture was hence searched for. The aim of this study was to review the literature regarding the influence of head and tongue posture on the pharyngeal airway morphology and dimensions using three-dimensional imaging (CT, CBCT or MRI). The hypothesis from the authors was that in the available literature valid evidence is present regarding the effect of head and tongue posture on the upper airway dimensions and morphology evaluated on CT, CBCT or MRI scanning.

To the best of our knowledge, no systematic literature review has been published regarding this topic. Consequently this topic had to be explored in order to present a standardized method that can be useful in upper airway analysis. Valid information of the upper airway dimensions/volume constitutes an important knowledge for the evaluation of OSA and to assess the influence of the different orthognathic surgical procedures on upper airway. 
As summarized in Table 3, Ono et al. [38], PiriläParkkinen et al. [39] and Zhang et al. [43], comprised non-randomized controlled trials. However, these studies used a prospective design with the focus on the effect of different head and body positions on upper airway dimensions and volume exclusively evaluated by MRI. Glupker et al. [44] was a retrospective study concerning the effects of open and closed jaw positions on the volume and crosssectional area of the upper airway exclusively performed using CBCT.

These studies were not comparable due to the heterogeneous methodology in conjunction with disorders related to the upper airway. In order to assess the validity and accuracy of the four included studies for the purpose of performing a metaanalysis, the scales by Jadad et al. [45] and Verhagen et al. [46] were reviewed. However, again due to the heterogeneous methodologies and the lack of randomized controlled studies, a narrative synthesis was found more appropriate as the method of assessing the quality of the studies.

Ono et al. [38] studied upper airway related to three head/body positions, supine, supine with the head rotated and lateral recumbent and showed significant increase in volume in the retro-glossal region of oropharynx when the subject rotated his head to left in the supine position and when changing from the supine to the lateral recumbent position. Valid numeric values regarding the volume were missing in the study [38].

Pirilä-Parkkinen et al. [39] studied three different head postures in two groups of each 29 children. The test group comprised subjects with sleep-disordered breathing (SDB), while the control group of age- and gender-matched healthy children: in both groups the upper airway were evaluated in neutral, extension, and flexion positions of the head. The hypopharyngeal airway in the SDB group increased by head extension compared to NHP. The increase was higher for the SDB group than in the asymptomatic group [39].

Zhang et al. [43] studied the upper airway in 12 patients with no sign of breathing-related disorders. Four different jaw, head and body positions were evaluated: jaw protrusion, supine with jaw protrusion, supine-head rotation with jaw protrusion and lateral decubitus with jaw protrusion. The study showed that jaw protrusion increased the volume of oropharynx at the level of the retro-palatal- and the retro-glossal regions compared with non-protruded positions [43]. Glupker et al. [44] in a CBCT retrospective study assessed open and closed jaw positions in relation to upper airway dimensions on 60 females undergoing diagnosis and treatment of temporomandibular disorders. The study indicated that open jaw position compared to closed jaw position might cause a significant increase in the volume of the nasopharynx, whereas the nasal cavity volume, the oropharyngeal volume, and the soft palate area decrease [44].

The results from Glupker et al. [44] seem to contradict the studies by Ono et al. [38], Pirilä-Parkkinen et al. [39] and Zhang et al. [43]. Where Glupker et al. [44] found a decrease in the volume of the oropharynx, the other studies showed an increase. The anatomic landmarks and the subdivision of the anatomic regions of the pharyngeal airway used in this study were however different from the recommended and hence a major obstacle for comparison with other studies arises [ㄴ, $\underline{6}, \underline{25}]$.

Due to the lack of a precise subregion definition of the pharyngeal airway in the literature, different studies use different anatomic boundaries for the evaluation of the upper airway, thus making a comparison among studies very difficult $[8,13,16,25,47]$.

In order to standardize upper airway analysis, the pharyngeal airway has been subdivided into 3 anatomic regions by Hudgel [48], Van Lunteren [49] and Schwab [50]: nasopharynx, oropharynx, and hypopharynx. Oropharynx can be further divided into the retro-palatal and the retro-glossal regions. This anatomic division has been subsequently used in several studies $[\underline{38}, \underline{39}, \underline{43}]$ and recently confirmed by Guijarro-Martínez et al. [25], that the subdivision is clinically reasonable, technically convenient, and statistically reliable.

The main findings of the included studies were that altered head, body and jaw position, respectively had a significant effect on the upper airway dimensions and volume at the time of image acquisition. The oropharyngeal airway and specifically the retropalatal and retro-glossal regions of the oropharynx, seem to be the most affected part of the upper airway when evaluated in respect to head rotation, head extension, jaw protrusion and altered body position $[38,39,43]$. The volume and the cross-sectional areas of the oropharynx increased as a response to head extension, head rotation, lateral recumbent body position and jaw protrusion $[38,39,43]$.

The main limitation of the studies was the methodology, since no validated method existed with regard to the position of head, jaw or body at the time of image acquisition. For instance, in the MRI studies by Ono et al. [38] and Pirilä-Parkkinen et al. [39], an air pillow and a foam bolster respectively were used for the stabilization of head posture in different positions and this method will undoubtedly lead to some differences in the degree of the craniocervical inclination and thus creating invalid results. 
In the included studies the method of upper airway segmentation whether done manually or automated was missing, which is also judged as a limitation [51]. The image acquisition time was reported to be between 3 and 5 minutes in the MRI studies, which is a long time $[38,39,43]$. Even well instructed with regard to avoidance of study subject movement, swallowing, talking and attempting quiet nose breathing during the image acquisition, these factors would most likely have some input on the results as well. The methodological scoring and the quality of the studies, as summarized in Table 5, ranged from $46 \%$ to $67 \%$ of the maximum achievable with a mean quality of $54 \%$, which is according to van Vlijmen et al. [10] considered as poor quality and low level of evidence.

In spite of only few articles studying the effect of head posture with a doubtful quality, it's however obvious that there exists a correlation between altered head or body posture and upper airway dimensions, when evaluated by three-dimensional CBCT or MRI. Nevertheless none of the studies were using a validated and standardized method for head posture and consequently these results have to be interpreted with caution.

Another factor of importance when evaluating upper airways is breathing during image acquisition. Normally 40 seconds are required for a full head image on CBCT, why it is customary to ask the patient to breathe gently during the session.

\section{CONCLUSIONS}

Based on the available literature, valid evidence on a standardized method for head and tongue positioning during three-dimensional image acquisitions is lacking.
Natural head position at cone-beam computed tomography acquisition is the suggested standardized posture. However, for repeatable measures of upper airway volumes it may clinically be difficult to obtain. This literature review revealed, that in the current published literature there is no valid information on, how an altered head posture from the natural head position will influence on upper airway dimensions and morphology during cone-beam computed tomography or magnetic resonance imaging acquisition. This may have an impact on the comparison of the airway volumes in conjunction with outcome measures of different treatment modalities. In the same context, breathing during imaging should be taken into consideration.

Studies concerning the effect of tongue posture on upper airway dimensions and morphology were lacking in the literature and we did not succeed to discover any paper dealing with this issue.

Despite the big interest of upper airway evaluation and improvement of three-dimensional airway analysis by cone-beam computed tomography, a standardized and validated method for head and tongue positioning is essential when evaluating upper airway dimensions in cone-beam computed tomography or magnetic resonance imaging acquisition and future studies need to focus on its development.

\section{ACKNOWLEDGMENTS AND DISCLOSURE STATEMENTS}

The authors report no conflicts of interest related to this study. The authors would like to thank "research librarian Janne Lytoft Simonsen, Aarhus University, Denmark" and "librarian Peter Everfelt, Medical Library, Hospital of Southwest Denmark" for their great help during the computerized searches of the databases.

\section{REFERENCES}

1. Ciscar MA, Juan G, Martínez V, Ramón M, Lloret T, Mínguez J, Armengot M, Marín J, Basterra J. Magnetic resonance imaging of the pharynx in OSA patients and healthy subjects. Eur Respir J. 2001 Jan;17(1):79-86. [Medline: 11307760] [doi: 10.1183/09031936.01.17100790]

2. Schwab RJ, Gefter WB, Hoffman EA, Gupta KB, Pack AI. Dynamic upper airway imaging during awake respiration in normal subjects and patients with sleep disordered breathing. Am Rev Respir Dis. 1993 Nov;148(5):1385-400. [Medline: 8239180] [doi: 10.1164/ajrccm/148.5.1385]

3. Suratt PM, Dee P, Atkinson RL, Armstrong P, Wilhoit SC. Fluoroscopic and computed tomographic features of the pharyngeal airway in obstructive sleep apnea. Am Rev Respir Dis. 1983 Apr;127(4):487-92. [Medline: 6838055] [doi: 10.1097/00004728-198312000-00059]

4. Lenza MG, Lenza MM, Dalstra M, Melsen B, Cattaneo PM. An analysis of different approaches to the assessment of upper airway morphology: a CBCT study. Orthod Craniofac Res. 2010 May;13(2):96-105. [Medline: 20477969] [doi: $10.1111 / \mathrm{j} .1601-6343.2010 .01482 . x$ ] 
5. Abbott MB, Donnelly LF, Dardzinski BJ, Poe SA, Chini BA, Amin RS. Obstructive sleep apnea: MR imaging volume segmentation analysis. Radiology. 2004 Sep;232(3):889-95. [Medline: 15333801] [doi: 10.1148/radiol.2323031581]

6. Schwab RJ. Upper airway imaging. Clin Chest Med. 1998 Mar;19(1):33-54. [Medline: 9554216] [doi: 10.1016/S0272-5231(05)70430-5]

7. Di Carlo G, Polimeni A, Melsen B, Cattaneo PM. The relationship between upper airways and craniofacial morphology studied in 3D. A CBCT study. Orthod Craniofacn Res. 2015 Feb;18(1):1-11. [Medline: 25237711] [doi: 10.1111/ocr.12053]

8. Guijarro-Martínez R, Swennen GR. Cone-beam computerized tomography imaging and analysis of the upper airway: a systematic review of the literature. Int J Oral Maxillofac Surg. 2011 Nov;40(11):1227-37. [Medline: 21764260] [doi: 10.1016/j.ijom.2011.06.017]

9. McCrillis JM, Haskell J, Haskell BS, Brammer M, Chenin D, Scarfe WC, Farma AG. Obstructive sleep apnea and the use of cone beam computed tomography in airway imaging: a review. Semin Orthod. 2009 Mar;(15)1:63-9. [doi: 10.1053/i.sodo.2008.09.008]

10. van Vlijmen OJ, Kuijpers MA, Bergé SJ, Schols JG, Maal TJ, Breuning H, Kuijpers-Jagtman AM. Evidence supporting the use of cone-beam computed tomography in orthodontics. J Am Dent Assoc. 2012 Mar;143(3):241-52. [Medline: 22383204] [doi: 10.14219/jada.archive.2012.0148]

11. Aboudara C, Nielsen I, Huang JC, Maki K, Miller AJ, Hatcher D. Comparison of airway space with conventional lateral headfilms and 3-dimensional reconstruction from cone-beam computed tomography. Am J Orthod Dentofacial Orthop. 2009 Apr;135(4):468-79. [Medline: 19361733] [doi: 10.1016/j.ajodo.2007.04.043]

12. Cattaneo PM, Melsen B. The use of cone-beam computed tomography in an orthodontic department in between research and daily clinic. World J Orthod. 2008 Fall;9(3):269-82. [Medline: 18834009]

13. El H, Palomo JM. Measuring the airway in 3 dimensions: a reliability and accuracy study. Am J Orthod Dentofacial Orthop. 2010 Apr;137(4 Suppl):S50.e1-9; discussion S50-2. [Medline: 20381759] [doi: 10.1016/j.ajodo.2010.01.014]

14. Ghoneima A, Kula K. Accuracy and reliability of cone-beam computed tomography for airway volume analysis. Eur J Orthod. 2013 Apr;35(2):256-61. [Medline: 21832270] [doi: 10.1093/ejo/cjr099]

15. Iwasaki T, Saitoh I, Takemoto Y, Inada E, Kakuno E, Kanomi R, Hayasaki H, Yamasaki Y. Tongue posture improvement and pharyngeal airway enlargement as secondary effects of rapid maxillary expansion: a cone-beam computed tomography study. Am J Orthod Dentofacial Orthop. 2013 Feb;143(2):235-45. [Medline: 23374931] [doi: 10.1016/j.ajodo.2012.09.014]

16. Kim MA, Kim BR, Youn JK, Kim YJ, Park YH. Head posture and pharyngeal airway volume changes after bimaxillary surgery for mandibular prognathism. J Craniomaxillofac Surg. 2014 Jul;42(5):531-5. [Medline: 24080139] [doi: 10.1016/j.jems.2013.07.022]

17. Ribeiro AN, de Paiva JB, Rino-Neto J, Illipronti-Filho E, Trivino T, Fantini SM. Upper airway expansion after rapid maxillary expansion evaluated with cone beam computed tomography. Angle Orthod. 2012 May;82(3):458-63. [Medline: 21999215] [doi: 10.2319/030411-157.1]

18. Valladares-Neto J, Silva MA, Bumann A, Paiva JB, Rino-Neto J. Effects of mandibular advancement surgery combined with minimal maxillary displacement on the volume and most restricted cross-sectional area of the pharyngeal airway. Int J Oral Maxillofac Surg. 2013 Nov;42(11):1437-45. [Medline: 23702371] [doi: 10.1016/j.ijom.2013.03.018]

19. Bettega G, Pépin JL, Veale D, Deschaux C, Raphaël B, Lévy P. Obstructive sleep apnea syndrome. fifty-one consecutive patients treated by maxillofacial surgery. Am J Respir Crit Care Med. 2000 Aug;162(2 Pt 1):641-9. [Medline: 10934100] [doi: 10.1164/ajrccm.162.2.9904058]

20. Holty JE, Guilleminault C. Maxillomandibular advancement for the treatment of obstructive sleep apnea: a systematic review and meta-analysis. Sleep Med Rev. 2010 Oct;14(5):287-97. [Medline:20189852] [doi: 10.1016/j.smrv.2009.11.003]

21. Knudsen TB, Laulund AS, Ingerslev J, Homøe P, Pinholt EM. Improved apnea-hypopnea index and lowest oxygen saturation after maxillomandibular advancement with or without counterclockwise rotation in patients with obstructive sleep apnea: a meta-analysis. J Oral Maxillofac Surg. 2015 Apr;73(4):719-26. [Medline: 25443377] [doi: 10.1016/j.joms.2014.08.006]

22. Lee Y, Chun YS, Kang N, Kim M. Volumetric changes in the upper airway after bimaxillary surgery for skeletal class III malocclusions: a case series study using 3-dimensional cone-beam computed tomography. J Oral Maxillofac Surg. 2012 Dec;70(12):2867-75. [Medline: 22682739] [doi: 10.1016/j.joms.2012.03.007]

23. Jakobsone G, Neimane L, Krumina G. Two- and three-dimensional evaluation of the upper airway after bimaxillary correction of Class III malocclusion. Oral Surg Oral Med Oral Pathol Oral Radiol Endod. 2010 Aug;110(2):234-42. [doi: 10.1016/j.tripleo.2010.03.026]

24. Hong JS, Park YH, Kim YJ, Hong SM, Oh KM. Three-dimensional changes in pharyngeal airway in skeletal class III patients undergoing orthognathic surgery. J Oral Maxillofac Surg. 2011 Nov;69(11):e401-8. [Medline: 21571419] [doi: 10.1016/i.joms.2011.02.011]

25. Guijarro-Martínez R, Swennen GR. Three-dimensional cone beam computed tomography definition of the anatomical subregions of the upper airway: a validation study. Int J Oral Maxillofac Surg. 2013 Sep;42(9):1140-9. [Medline: 23623785] [doi: 10.1016/j.ijom.2013.03.007] 
26. Hellsing E. Changes in the pharyngeal airway in relation to extension of the head. Eur J Orthod. 1989 Nov;11(4):359-65. [Medline: 2591483]

27. Muto T, Takeda S, Kanazawa M, Yamazaki A, Fujiwara Y, Mizoguchi I. The effect of head posture on the pharyngeal airway space (PAS). Int J Oral Maxillofac Surg. 2002 Dec;31(6):579-83. [Medline: 12521311] [doi: 10.1054/ijom.2002.0279]

28. Moorrees CFA, Kean MR. Natural head position, a basic consideration in the interpretation of cephalometric radiographs. Am J Phys Anthropol. 1958 Jun;16(2):213-34. [doi: 10.1002/ajpa.1330160206]

29. Solow B, Ovesen J, Nielsen PW, Wildschiødtz G, Tallgren A. Head posture in obstructive sleep apnoea. Eur J Orthod. 1993 Apr;15(2):107-14. [Medline: 8500536] [doi: 10.1093/ejo/15.2.107]

30. Solow B, Skov S, Ovesen J, Norup PW, Wildschiødtz G. Airway dimensions and head posture in obstructive sleep apnoea. Eur J Orthod. 1996 Dec;18(6):571-9. [Medline: 9009421] [doi: 10.1093/ejo/18.6.571]

31. Solow B, Sandham A. Cranio-cervical posture: a factor in the development and function of the dentofacial structures. Eur J Orthod. 2002 Oct;24(5):447-56. [Medline: 12407940] [doi: 10.1093/ejo/24.5.447]

32. Wickwire NA, White RP Jr, Proffit WR. The effect of mandibular osteotomy on tongue position. J Oral Surg. 1972 Mar;30(3):184-90. [Medline: 4501095]

33. Aydemir H, Memikoğlu U, Karasu H. Pharyngeal airway space, hyoid bone position and head posture after orthognathic surgery in Class III patients. Angle Orthod. 2012 Nov;82(6):993-1000. [Medline: 22500578] [doi: 10.2319/091911-597.1]

34. Efendiyeva R, Aydemir H, Karasu H, Toygar-Memikoğlu U. Pharyngeal airway space, hyoid bone position, and head posture after bimaxillary orthognathic surgery in Class III patients: long-term evaluation. Angle Orthod. 2014 Sep;84(5):773-81. [Medline: 24601894] [doi: 10.2319/072213-534.1]

35. Achilleos S, Krogstad O, Lyberg T. Surgical mandibular advancement and changes in uvuloglossopharyngeal morphology and head posture: a short- and long-term cephalometric study in males. Eur J Orthod. 2000 Aug;22(4):367-81. [Medline: 11029826] [doi: 10.1093/ejo/22.4.367]

36. Lagravere MO, Major PW, Flores-Mir C. Long-term skeletal changes with rapid maxillary expansion: a systematic review. Angle Orthod. 2005 Nov;75(6):1046-52. [Medline: 16448254]

37. Roscoe MG, Meira JB, Cattaneo PM. Association of orthodontic force system and root resorption: A systematic review. Am J Orthod Dentofacial Orthop. 2015 May;147(5):610-26. doi: 10.1016/j.ajodo.2014.12.026. [Medline: 25919107] [doi: 10.1016/j.ajodo.2014.12.026]

38. Ono T, Otsuka R, KurodaT,HondaE, SasakiT.Effects of head and body position on two-and three-dimensional configurations of the upper airway. J Dent Res. 2000 Nov;79(11):1879-84. [Medline: 11145359] [doi: 10.1177/00220345000790111101]

39. Pirilä-Parkkinen K, Pirttiniemi P, Pääkkö E, Tolonen U, Nieminen P, Löppönen H. Pharyngeal airway in children with sleep-disordered breathing in relation to head posture. Sleep Breath. 2012 Sep;16(3):737-46. [Medline: 21826530] [doi: 10.1007/s11325-011-0569-y]

40. Knudsen TB, Laulund AS, Ingerslev J, Homøe P, Pinholt EM. Improved apnea-hypopnea index and lowest oxygen saturation after maxillomandibular advancement with or without counterclockwise rotation in patients with obstructive sleep apnea: a meta-analysis. J Oral Maxillofac Surg. 2015 Apr;73(4):719-26. [Medline: 25443377] [doi: 10.1016/j.joms.2014.08.006]

41. Muto T, Yamazaki A, Takeda S, Kawakami J, Tsuji Y, Shibata T, Mizoguchi I. Relationship between the pharyngeal airway space and craniofacial morphology, taking into account head posture. Int J Oral Maxillofac Surg. 2006 Feb;35(2):132-6. [Medline: 15961280] [doi: $10.1016 / j . i j o m .2005 .04 .022]$

42. Cevidanes L, Oliveira AE, Motta A, Phillips C, Burke B, Tyndall D. Head orientation in CBCT-generated cephalograms. Angle Orthod. 2009 Sep;79(5):971-7. [Medline: 19705941] [PMC free article: 273394] [doi: 10.2319/090208-460.1]

43. Zhang W, Song X, Masumi SI, Tanaka T, Zhu Q. Effects of head and body positions on 2- and 3-dimensional configuration of the oropharynx with jaw protruded: a magnetic resonance imaging study. Oral Surg Oral Med Oral Pathol Oral Radiol Endod. 2011 Jun;111(6):778-84. [Medline: 21569991] [doi: 10.1016/j.tripleo.2011.02.019]

44. Glupker L, Kula K, Parks E, Babler W, Stewart K, Ghoneima A. Three-dimensional computed tomography analysis of airway volume changes between open and closed jaw positions. Am J Orthod Dentofacial Orthop. 2015 Apr;147(4): 426-34. [Medline: 25836002] [doi: 10.1016/j.ajodo.2014.11.025]

45. Jadad AR, Moore RA, Carroll D, Jenkinson C, Reynolds DJ, Gavaghan DJ, McQuay HJ. Assessing the quality of reports of randomized clinical trials: is blinding necessary? Control Clin Trials. 1996 Feb;17(1):1-12. [Medline: 8721797] [doi: 10.1016/0197-2456(95)00134-4]

46. Verhagen AP, de Vet HC, de Bie RA, Kessels AG, Boers M, Bouter LM, Knipschild PG. The Delphi list: a criteria list for quality assessment of randomized clinical trials for conducting systematic reviews developed by Delphi consensus. J Clin Epidemiol. 1998 Dec;51(12):1235-41. [Medline: 10086815] [doi: 10.1016/S0895-4356(98)00131-0]

47. Hong JS, Oh KM, Kim BR, Kim YJ, Park YH. Three-dimensional analysis of pharyngeal airway volume in adults with anterior position of the mandible. Am J Orthod Dentofacial Orthop. 2011 Oct;140(4):e161-9. [Medline: 21967954] [doi: 10.1016/j.ajodo.2011.04.020]

48. Hudgel DW. The role of upper airway anatomy and physiology in obstructive sleep apnea. Clin Chest Med. 1992 Sep;13(3):383-98. [Medline: 1521408] 
49. van Lunteren E. Muscles of the pharynx: structural and contractile properties. Ear Nose Throat J. 1993 Jan;72(1):27-9, 33. [Medline: $\underline{8444123]}$

50. Schwab RJ, Gupta KB, Gefter WB, Metzger LJ, Hoffman EA, Pack AI. Upper airway and soft tissue anatomy in normal subjects and patients with sleep-disordered breathing. Significance of the lateral pharyngeal walls. Am J Respir Crit Care Med. 1995 Nov;152(5 Pt 1):1673-89. [Medline: 7582313] [doi: 10.1164/ajrccm.152.5.7582313]

51. Alsufyani NA, Al-Saleh MA, Major PW. CBCT assessment of upper airway changes and treatment outcomes of obstructive sleep apnoea: a systematic review. Sleep Breath. 2013 Sep;17(3):911-23. [Medline: 23344828] [doi: 10.1007/s11325-012-0799-7]

\section{To cite this article:}

Gurani SF, Di Carlo G, Cattaneo PM, Thorn JJ, Pinholt EM.

Effect of Head and Tongue Posture on the Pharyngeal Airway Dimensions and Morphology in Three-Dimensional Imaging: a Systematic Review

J Oral Maxillofac Res 2016;7(1):e1

URL: http://www.ejomr.org/JOMR/archives/2016/1/e1/v7n1e1.pdf

doi: $10.5037 /$ jomr.2016.7101

Copyright (C) Gurani SF, Di Carlo G, Cattaneo PM, Thorn JJ, Pinholt EM. Published in the JOURNAL OF ORAL \& MAXILLOFACIAL RESEARCH (http://www.ejomr.org), 31 March 2016.

This is an open-access article, first published in the JOURNAL OF ORAL \& MAXILLOFACIAL RESEARCH, distributed under the terms of the Creative Commons Attribution-Noncommercial-No Derivative Works 3.0 Unported License, which permits unrestricted non-commercial use, distribution, and reproduction in any medium, provided the original work and is properly cited. The copyright, license information and link to the original publication on (http://www.ejomr.org) must be included. 